Louisiana State University

LSU Digital Commons

Faculty Publications

Department of Biological Sciences

$1-1-2014$

\title{
Specimen collection: An essential tool
}

L. A. Rocha

California Academy of Sciences

A. Aleixo

Museu Paraense Emilio Goeldi

G. Allen

Western Australian Museum

F. Almeda

California Academy of Sciences

C. C. Baldwin

Smithsonian Institution

See next page for additional authors

Follow this and additional works at: https://digitalcommons.Isu.edu/biosci_pubs

\section{Recommended Citation}

Rocha, L., Aleixo, A., Allen, G., Almeda, F., Baldwin, C., Barclay, M., Bates, J., Bauer, A., Benzoni, F., Berns, C., Berumen, M., Blackburn, D., Blum, S., Bolaños, F., Bowie, R., Britz, R., Brown, R., Cadena, C., Carpenter, K., Ceríaco, L., Chakrabarty, P., Chaves, G., Choat, J., Clements, K., Collette, B., Collins, A., Coyne, J., Cracraft, J., Daniel, T., De Carvalho, M., De Queiroz, K., Di Dario, F., \& Drewes, R. (2014). Specimen collection: An essential tool. Science, 344 (6186), 814-815. https://doi.org/10.1126/science.344.6186.814

This Letter to the Editor is brought to you for free and open access by the Department of Biological Sciences at LSU Digital Commons. It has been accepted for inclusion in Faculty Publications by an authorized administrator of LSU Digital Commons. For more information, please contact ir@lsu.edu. 


\section{Authors}

L. A. Rocha, A. Aleixo, G. Allen, F. Almeda, C. C. Baldwin, M. V.L. Barclay, J. M. Bates, A. M. Bauer, F. Benzoni, C. M. Berns, M. L. Berumen, D. C. Blackburn, S. Blum, F. Bolaños, R. C.K. Bowie, R. Britz, R. M.

Brown, C. D. Cadena, K. Carpenter, L. M. Ceríaco, P. Chakrabarty, G. Chaves, J. H. Choat, K. D. Clements, B. B. Collette, A. Collins, J. Coyne, J. Cracraft, T. Daniel, M. R. De Carvalho, K. De Queiroz, F. Di Dario, and R. Drewes 


\section{LETTERS}

Edited by Jennifer Sills

\section{Specimen collection: An essential tool}

COLLECTING BIOLOGICAL specimens for scientific studies came under scrutiny when B. A. Minteer et al. ["Avoiding (re)extinction," Perspectives, 18 April, p. 260] suggested that this practice plays a significant role in species extinctions. Based on a small number of examples (rare birds, frogs, and a few plants), the authors concluded that collection of voucher specimens is potentially harmful to many species, and that alternativesphotographs, audio recordings and nonlethal tissue sampling for DNA analysis-are sufficient to document biological diversity.

The isolated examples that Minteer et al. cited to demonstrate the negative impact of scientific collecting have been carefully analyzed, and none of these extinction events can be attributed to that cause (1-3). For example, only about 102 Great Auk specimens (Pinguinus impennis) exist today in scientific collections, many of which are skeletons obtained after extinction, whereas millions were harvested for food, oil, and feathers over millennia (1). Similarly, only nine Mexican elf owls (Micrathene whitneyi graysoni), endemic to Socorro Island, Mexico, are present in natural history collections. Field notes indicate that this species was common when specimens were collected between 1896 and 1932, and the most likely reasons for extinction around 1970 were habitat degradation and predation by invasive species (2).

Scientists have come a long way from the days of indiscriminate collecting. Modern collecting adheres to strict permitting regulations and ethics guidelines, including the general practice of collecting a number of specimens substantially below levels that would affect population demography $(3,4)$. The suggested alternatives to collecting specimens (photographing, recording calls, or sampling tissue nonlethally) are individually problematic, and even together cannot be used to reliably identify or describe the vast majority of Earth's biodiversity [for example, a large proportion of the world's marine biodiversity is hidden deep in its habitat (see image)]. Moreover, identification is often not the most important reason to collect voucher specimens. Studies of morphological diversity and its evolution are impossible without whole specimens. Preserved specimens also provide verifiable data points for monitoring species health, distribution, and phenotypes through time. Both historical and new collections played a key role in understanding the spread of the chytrid fungus infection, one of the greatest current threats to amphibians (5). The decision to ban dichlorodiphenyltrichloroethane (DDT) distract from the primary causes of modern extinction: habitat degradation and loss, unsustainable harvesting, and invasive species (10). It is important to distinguish protecting the lives of individuals from conserving populations and species. Individuals are lost every day to predation, natural death, and anthropogenic factors, hence it is the populations we try to save. Halting collection of voucher specimens by scientists would be detrimental not only to our understanding of Earth's diverse biota and its biological processes, but also for conservation and management efforts. Species descriptions, biodiversity

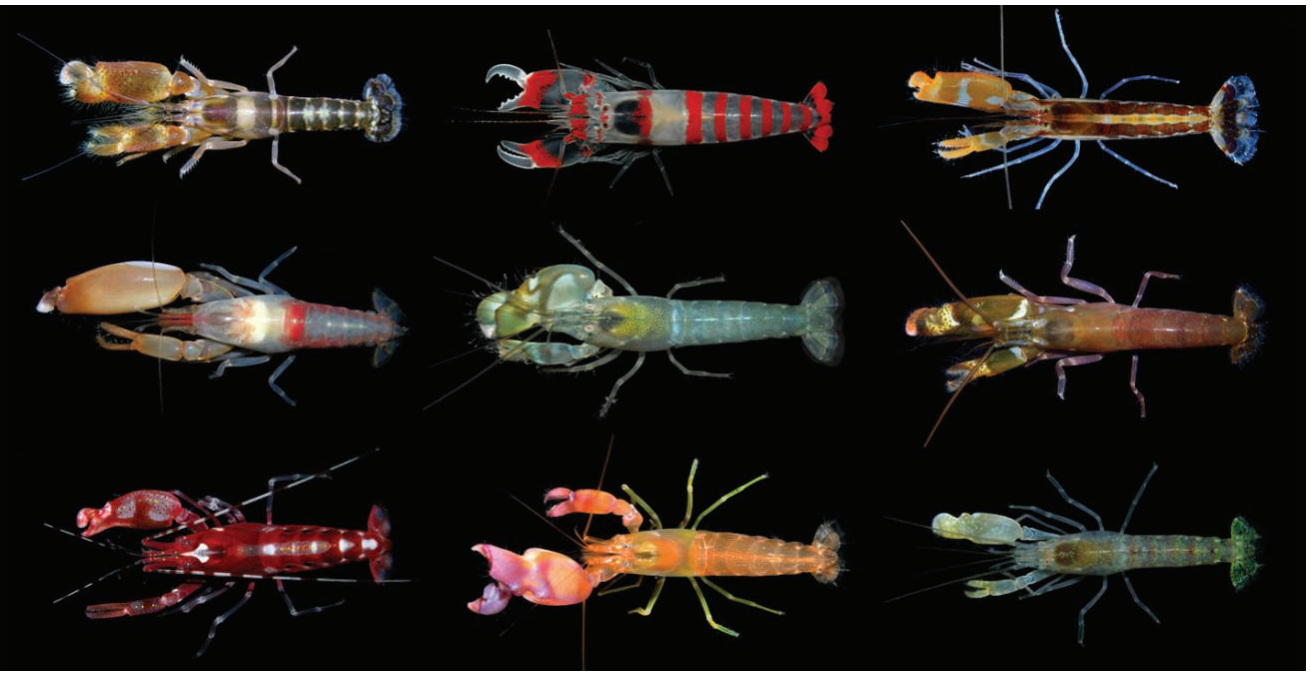

Undercover. Many Alpheidae shrimps live deep in the reef and are impossible to collect nonlethally. and other environmental pollutants was the result of the discovery of thinning of bird eggshells collected over an extended period (6). One of the negative effects of climate change, declining body size in animals, was only discovered with morphological data from museum specimens (7). Furthermore, IUCN Red List criteria require specific and detailed information about life history and biology (such as longevity and growth rate), especially for widely distributed species; therefore, without specimens, the extinction risk of many species cannot be properly assessed (8). Most specimens were not collected with these objectives in mind, and this is a hallmark of biological collections: They are often used in ways that the original collector never imagined. With new technologies continuing to emerge (such as stable isotope analyses, massive parallel sequencing, and CT-scan tomography), scientific collections are becoming even more important for studies of ecology, evolution, and conservation (9).

The arguments of Minteer et al. erroneously portray the critical importance of scientific collecting in a negative light and inventories, and the identification of areas of endemism are just some of the basic information that can be obtained from specimens and collections-based research. Such knowledge, with its rich temporal and spatial dimensions, has proven fundamental in designing conservation areas and in making environmental impact assessments (11). These issues are particularly relevant in many developing nations, which ideally must seek a balance between the conservation of their natural (biological) resources and development. One example comes from the Bird's Head Peninsula of New Guinea, Indonesia, where the discovery and description of small endemic species-undetectable without specimen collection-directly resulted in the creation of several new protected areas and increased support for marine parks (12).

With our ever-increasing footprint, humans now affect even the most remote corners of Earth. Because an estimated $86 \%$ of species on the planet remain unknown (13), our goal should be to document biodiversity as rigorously as possible through carefully planned collections so that it can be effectively preserved 
and understood. Specimens from such collections and their associated data are essential for making informed decisions about management and conservation now and in the future. As a community, we advocate the utmost responsibility and care while making scientific collections (4). Furthermore, given increasing rates of habitat loss and global change, we believe that responsibly collecting voucher specimens and associated data and openly sharing this knowledge (for example, through GBIF, iDigBio, and VertNet) are more necessary today than ever before.

L.A. Rocha, ${ }^{1 *}$ A. Aleixo, ${ }^{2}$ G. Allen, ${ }^{3}$ F. Almeda, ${ }^{1}$ C. C. Baldwin, ${ }^{4}$ M. V. L. Barclay, ${ }^{5}$

J.M. Bates, ${ }^{6}$ A. M. Bauer, ${ }^{7}$ F. Benzoni, ${ }^{8}$

C.M. Berns, ${ }^{9}$ M. L. Berumen, ${ }^{10}$ D. C.

Blackburn, ${ }^{1}$ S. Blum, ${ }^{7}$ F. Bolaños, ${ }^{11}$ R. C. K. Borvie, ${ }^{12}$ R. Britz, ${ }^{5}$ R. M. Browen, ${ }^{13}$ C. D. Cadena, ${ }^{14}$ K. Carpenter, ${ }^{15}$ L. M. Ceríaco, ${ }^{16}$ P. Chakrabarty, ${ }^{17}$ G. Chaves, ${ }^{11}$ J. H. Choat, ${ }^{18}$ K. D. Clements, ${ }^{19}$ B. B. Collette, ${ }^{20}$ A. Collins, ${ }^{20}$ J. Coyne, ${ }^{21} \mathrm{~J}$. Cracraft, ${ }^{22}$ T. Daniel, ${ }^{1}$ M. R. de Carvalho, ${ }^{23}$

K. de Queiroz, ${ }^{4}$ F. Di Dario, ${ }^{24}$ R. Drewes, ${ }^{1}$ J. P. Dumbacher, ${ }^{1}$ A. Engilis Jr., ${ }^{25} M$. V. Erdmann, ${ }^{26}$ W. Eschmeyer, ${ }^{1}$ C. $R$. Feldman, ${ }^{27}$ B. L. Fisher, ${ }^{1}$ J. Fjeldså, ${ }^{28} P$. W. Fritsch, ${ }^{1}$ J. Fuchs, ${ }^{29}$ A. Getahun, ${ }^{30} A$. Gill, ${ }^{31}$ M. Gomon, ${ }^{32}$ T. Gosliner, ${ }^{1}$ G. R. Graves, ${ }^{4}$ C. E. Griswold, ${ }^{1}$ R. Guralnick, ${ }^{33}$ K. Hartel, ${ }^{34}$ K. M. Helgen, ${ }^{4}$ H. Ho, ${ }^{35}$ D. T. Iskandar, ${ }^{36}$ T. Irwamoto, ${ }^{1}$ Z. Jaafar, ${ }^{4,37} \mathrm{H}$. F. James, ${ }^{4}$ D. Johnson, ${ }^{4}$ D. Kavanaugh, ${ }^{1}$

N. Knowiton, ${ }^{4}$ E. Lacey, ${ }^{12}$ H. K. Larson, ${ }^{38}$ P. Last, ${ }^{39}$ J. M. Leis, ${ }^{40}$ H. Lessios, ${ }^{41}$ J. Liebherr, ${ }^{42}$ M. Lowman, ${ }^{1}$ D. L. Mahler, ${ }^{25}$ V. Mamonekene, ${ }^{43}$ K. Matsuura, ${ }^{44}$ G. C. Mayer, ${ }^{45}$ H. Mays Jr., ${ }^{46}$ J. McCosker, ${ }^{1}$ R. W. McDiarmid, ${ }^{4}$ J. McGuire, ${ }^{12}$ M. J. Miller, ${ }^{41}$ R. Mooi, ${ }^{1}$ R. D. Mooi, ${ }^{47}$ C. Moritz, ${ }^{48}$ P. Myers, ${ }^{49}$ M. W. Nachman, ${ }^{12}$ R. A. Nussbaum, ${ }^{49}$ D. Ó Foighil, ${ }^{49}$ L. R. Parenti, ${ }^{4}$ J. F. Parham, ${ }^{50}$ E. Paul, ${ }^{51}$ G. Paulay, ${ }^{52} J$. Pérez-Emán, ${ }^{53}$ A. Pérez-Matus, ${ }^{54}$ S. Poe, ${ }^{55}$ J. Pogonoski, ${ }^{39}$ D. L. Rabosky, ${ }^{49}$ J. E. Randall, ${ }^{56}$ J. D. Reimer, ${ }^{57}$ D. R. Robertson, ${ }^{41}$ M.-O. Rödel, ${ }^{58}$ M. T. Rodrigues, ${ }^{23} P$. Roopnarine, ${ }^{1}$ L. Rüber, ${ }^{59}$ M. J. Ryan, ${ }^{55} F$. Sheldon, ${ }^{17}$ G. Shinohara, ${ }^{44}$ A. Short, ${ }^{13}$ W. B. Simison, ${ }^{1}$ W. F. Smith-Vaniz, ${ }^{52}$ V. G. Springer, ${ }^{4}$ M. Stiassny, ${ }^{22}$ J. G. Tello, ${ }^{22,60} \mathrm{C}$. W. Thompson, ${ }^{49}$ T. Trnski, ${ }^{61}$ P. Tucker, ${ }^{49}$

T. Valqui, ${ }^{62}$ M. Vecchione, ${ }^{20}$ E. Verheyen, ${ }^{63}$ P. C. Wainwright, ${ }^{25}$ T. A. Wheeler, ${ }^{64}$ W. T. White, ${ }^{39} \mathrm{~K}$. Will, ${ }^{12}$ J. T. Williams, ${ }^{4}$ G. Williams, ${ }^{1}$ E. O. Wilson, ${ }^{34} \mathrm{~K}$. Winker, ${ }^{65} \mathrm{R}$. Winterbottom, ${ }^{66}$ C. C. Witt ${ }^{55}$

${ }^{1}$ California Academy of Sciences, San Francisco, CA 94118, USA. ${ }^{2}$ Museu Paraense Emílio Goeldi, Belém, PA, 66040-170, Brazil. ${ }^{3}$ Western Australian Museum, Perth, WA, 6986, Australia. ${ }^{4}$ Smithsonian Institution, Washington, DC 20560, USA. ${ }^{5}$ Natural History
Museum, London, SW7 5BD, UK. ${ }^{6}$ Field Museum of Natural History, Chicago, IL 60605, USA. Villanova University, Villanova, PA 19085, USA. ${ }^{8}$ University of Milano-Bicocca, Milan, 20126, Italy. ${ }^{\circledR}$ Utica College, Utica, NY 13502, USA. ${ }^{10}$ King Abdullah University of Science and Technology, Thuwal, 23955, Saudi Arabia. ${ }^{11}$ Universidad de Costa Rica, San José, 11501-2060, Costa Rica. ${ }^{12}$ University of California, Berkeley, CA 94720-3161, USA. ${ }^{13}$ University of Kansas, Lawrence, KS 66045, USA. ${ }^{14}$ Universidad de los Andes, Bogotá, 4976, Colombia. ${ }^{15}$ Old Dominion University, Norfolk, VA 23529, USA. ${ }^{16}$ Museu Nacional de História Natural e da Ciência, Lisbon, 7005638, Portugal. ${ }^{17}$ Louisiana State University, Baton Rouge, LA 70803, USA. ${ }^{18}$ James Cook University, Townsville, 4811, Australia. ${ }^{19}$ University of Auckland, Auckland, 1142, New Zealand. ${ }^{20}$ NOAA Systematics Laboratory, Washington, DC 20013, USA. ${ }^{21}$ University of Chicago, Chicago, IL 60637, USA. ${ }^{22}$ American Museum of Natural History, New York, NY 10024, USA. ${ }^{23}$ Universidade de São Paulo, São Paulo, SP 05508-090, Brazil. ${ }^{24}$ Universidade Federal do Rio de Janeiro, Macaé, RJ, 27965-045, Brazil. ${ }^{25}$ University of California, Davis, CA 95616, USA. ${ }^{26}$ Conservation International, Denpasar, Bali, 80235, Indonesia. ${ }^{27}$ University of Nevada, Reno, NV 89557-0314, USA. ${ }^{28}$ Natural History Museum of Denmark, Copenhagen,

DK-2100, Denmark. ${ }^{29}$ Muséum National d'Histoire Naturelle, Paris, 75005, France. ${ }^{30}$ Addis Ababa University, Addis Ababa, 1176, Ethiopia. ${ }^{31}$ University of Sydney, Sydney, NSW, 2006, Australia. ${ }^{32}$ Museum Victoria, Melbourne, 3001, VIC, Australia. ${ }^{33}$ University of Colorado, Boulder, CO 80309-0334, USA.

${ }^{34}$ Harvard University, Cambridge, MA 02138, USA.

${ }^{35}$ National Museum of Marine Biology \& Aquarium Pingtung, 944, Taiwan. ${ }^{36}$ Institut Teknologi Bandung,

Bandung 40132, Indonesia. ${ }^{37}$ National University of Singapore, 117543, Singapore. ${ }^{38}$ Museum and Art Gallery of the Northern Territory, Darwin, 0820, NT, Australia. ${ }^{39} \mathrm{CSIRO}$ Marine \& Atmospheric Research, Hobart, TAS, 7000, Australia. ${ }^{40}$ Australian Museum, Sydney, NSW, 2010, Australia. ${ }^{41}$ Smithsonian Tropical Research Institute, Balboa, 0843-03092, Panamá. ${ }^{42}$ Cornell University, Ithaca, NY 14853, USA

${ }^{43}$ Université Marien Ngouabi, Brazzaville, B.P. 69,

Republic of Congo. ${ }^{44}$ National Museum of Nature and Science, Tsukuba, 305-0005, Japan. ${ }^{45}$ University of Wisconsin-Parkside, Kenosha, WI 53141-2000, USA. ${ }^{46}$ Cincinnati Museum Center, Cincinnati, $\mathrm{OH}$ 45203, USA. ${ }^{47}$ The Manitoba Museum, Winnipeg,

MB, R3B 0N2, Canada. ${ }^{48}$ Australian National University, Canberra, ACT, 0200, Australia. ${ }^{49}$ University of Michigan, Ann Arbor, MI 48109-1079, USA. ${ }^{50}$ California State University, Fullerton, CA 92831, USA. ${ }^{51}$ The Ornithological Council, Chevy Chase, MD 20815, USA. ${ }^{52}$ University of Florida Gainesville, FL 32611, USA. ${ }^{53}$ Universidad Central de Venezuela, Caracas, 1041, Venezuela. ${ }^{54}$ Pontificia Universidad Católica de Chile, Santiago 6513677 Chile. ${ }^{55}$ University of New Mexico, Albuquerque, NM 87131-0001, USA. ${ }^{56}$ Bernice P. Bishop Museum, Honolulu, HI 96817, USA. ${ }^{57}$ University of the Ryukyus, Nishihara, 903-0213, Japan. ${ }^{58}$ Museum für Naturkunde, Berlin, 10115, Germany. ${ }^{59}$ Naturhistorisches Museum der Burgergemeinde Bern, Bern, CH-3005, Switzerland. ${ }^{60}$ Long Island University, Brooklyn, NY 11201-8423, USA. ${ }^{61}$ Auckland Museum, Auckland, 1142, New Zealand ${ }^{62}$ Centro de Ornitologia y Biodiversidad, Lima, 33 Peru. ${ }^{63}$ Royal Belgian Institute of Natural Sciences, Brussels, 1000, Belgium. ${ }^{64} \mathrm{McGill}$ University, Montreal, QC, H9X 3V9, Canada. ${ }^{65}$ University of Alaska Museum, Fairbanks, AK 99775, USA. ${ }^{66}$ Royal Ontario Museum, Toronto, ON, M5S 2C6, Canada.

*Corresponding author. E-mail: LRocha@ calacademy.org

\section{REFERENCES}

1. E. Fuller, The Great Auk (H. N. Abrams, New York, 1999).

2. J.P. Hume, M. Walters, Extinction in Birds (Bloomsbury, London, 2012).

3. N. J. Collar, Bird Cons. Int. 10,1(2000)

4. K. Winker et al., Auk 127, 690 (2010)
5. T. L. Cheng, S. M. Rovito, D. B. Wake, V. T. Vredenburg, Proc. Natl.Acad. Sci.U.S.A.108,9502(2011)

6. R. D. Porter, S. N. Wiemeyer, Science 165, 199 (1969)

7. J. L. Gardner, A. Peters, M. R. Kearney, L. Joseph, R. Heinsohn, Trends Ecol. Evol. 26, 285 (2011).

8. Y. Sadovy de Mitcheson et al., Fish Fish. 14, 119 (2013)

9. K.Bietal.,Mol. Ecol.22,6018 (2013).

10. M. Clavero, E. Garcia-Berthou, Trends Ecol. Evol. 20,110 (2005).

11. B. Collen, N. Pettorelli, J. E. M. Baillie, S. M. Durant, Eds. Biodiversity Monitoring and Conservation: Bridging the Gap between Global Commitment and Local Action (Wiley, Cambridge, UK, 2013).

12. M.V. Erdmann, in Still counting...: Biodiversity Exploration for Conservation - the first 20 years of the Rapid Assessment Program, L. E. Alonso, J. L. Deichmann, S. A. McKenna, P. Naskrecki, S. J. Richards, Eds. (Conservation International, Arlington, VA, 2010).

13. C. Mora, D. P. Tittensor, S. Adl, A. G. B. Simpson, B. Worm, PLOS Biol. 9, e1001127 (2011).

\section{Specimen collection: Plan for the future}

WE WISH THAT B. A. Minteer et al.s claim that field biologists routinely collect voucher specimens were true ["Avoiding (re)extinction," Perspectives, 18 April, p. 260]. Any museum curator will tell you that it is a constant struggle to convince them to do so, despite countless publications rendered unreliable because it is impossible to verify species' identities. The necessity of voucher specimens varies by taxon and region, but in general, it is good practice to deposit them and as much data as possible, including DNA and photos in life.

We certainly do not wish to see any species driven to extinction by overcollecting, but submit that this is rare and more associated with commercial or ardent, recreational overcollecting than sensible scientific vouchering $(1,2)$. If the kill of a single individual increases the extinction risk of a species, then it is well below viable population size and already among the "walking dead."

Dawkins' description of evolution as improbability on a colossal scale is nowhere more evident than in morphology. Whether or not a species survives, museum specimens represent a window on many of its most remarkable novelties. Molecular data, although helpful in identifications, is neither a panacea nor surrogate for museum specimens, especially when it comes to newly discovered species. Describing a new species without depositing a holotype when a specimen can be preserved borders on taxonomic malpractice. Even given good photographs and a tissue sample, there are reasons to collect one or more complete specimens. We do not know what morphological characters will prove important in future studies of species status, phylogenetic 
relationships, or genetic or epigenetic variation. As taxonomists and ecologists, we do not want to know only that a species exists but to understand what makes it unique compared to related species. Given the importance of the phenotypeenvironment interface in natural selection, we potentially sacrifice the most important things to know about a species when we forego more than superficial evidence of anatomical details.

With millions of species threatened by extinction, it would be tragic were we left with no more than a few photographs and sequences as evidence they were once here. Given well-preserved specimens, we can continue to marvel at adaptations, discover models for biomimicry, refine theories of character transformations, and verify the state of internal or external structures discovered in related species. As the last generation with the opportunity to explore, discover, and document millions of species evolved over billions of years, we should not be so arrogant as to assume what science of the future may want or need.

Frank-T. Krell' and Quentin D. Wheeler ${ }^{2}$

${ }^{1}$ Department of Zoology, Denver Museum of Nature \& Science, Denver, C0 80205, USA. ${ }^{2}$ College of Environmental Science and Forestry. State

University of New York, Syracuse, NY 13210, USA.

*Corresponding author. E-mail: frank.krell@dmns.org

\section{REFERENCES}

1. D. A. Nortonetal., Taxon 43,181(1994).

2. K. Winker et al., Auk 127,690 (2010).

\section{Response}

THE PURPOSE OF OUR Perspective was to raise awareness about an issue that will increase in prevalence as the global biodiversity crisis unfolds: Absent a reliable estimate of population size, is it prudent and ethical to collect a newly observed individual of a species so rare it was thought extinct [e.g., (1)]? We support the work of natural history museums, and nowhere in our discussion did we argue that responsible collecting should be halted. Specimen collections provide invaluable contributions to many disciplines beyond taxonomy [e.g., $(2,3)]$; moreover, we continue to collect ourselves (J.P.C. and R.P.). We repeatedly emphasized that we were targeting the specific context of small and vulnerable populations only.

We would like to believe that we live in Rocha et al.'s world in which the responsible collector follows every regulation and ethical code (where these exist). Our own experience and research, however, paint a more complicated picture. A culture of responsible scientific practice is harder to establish than just following regulatory prescriptions and ethical injunctions (4). Rocha et al. also introduce a red herring by raising the distinction between individualand population- or species-level concern in conservation, which we understand and have discussed elsewhere (5). It is obvious that our Perspective concerns survival of populations and species; the individual specimen becomes important in our argument because of the small size of populations, especially when (as in the case of rediscovered amphibian populations) such individuals are found coexisting with the lethal pathogen that likely greatly reduced their numbers (6).

Nowhere do we claim that scientific collection is a leading driver of extinction. We are aware of the major threats posed by habitat loss and fragmentation, commercial use, exotic species, toxins, infectious diseases, and climate change (7). Collectors may have taken the last Auks, but the species was pushed to the brink of extinction by centuries of human overexploitation. Still, the point remains that without a reliable estimate of population size, collecting individuals from a small, isolated population can pose an extinction risk. We believe that it is important to highlight this risk, and to suggest how to mitigate the threat.

We are troubled by Krell and Wheeler's argument, which seems to suggest that collecting in vulnerable populations is justified as a way to preserve the present for a future in which many species will be extinct. Even small populations seem eligible for collecting based on their claim that such species are already among the "walking dead." If collecting a specimen increases extinction risk, however, then it is a threat to biodiversity and should be avoided. Krell and Wheeler object to the "arrogance" of assuming "what science of the future may want or need," but we find more hubris in their suggestion that taxonomists and ecologists should be unconcerned about driving the final nail in a species' coffin.

Cultural change in science can be difficult. Long-established techniques are questioned as alternatives arise. Specimen collection is no exception, especially in light of growing concerns about our entering a sixth mass extinction event (8), and we encourage more research into new ways to document Earth's biodiversity. A precautionary approach to scientific collection will help ensure that we do not put additional pressure on already vulnerable populations as we seek to identify organisms new to science, or to confirm a species' welcome return from the dead.

Ben A. Minteer, ${ }^{*}$ James P. Collins, ${ }^{1}$ Robert Puschendorf ${ }^{2}$
${ }^{1}$ School of Life Sciences, Arizona State University, Tempe, AZ 85287, USA. ${ }^{2}$ School of Biological Sciences, Plymouth University, Drake Circus, Plymouth, Devon PL4 8AA, UK.

*Corresponding author. E-mail: ben.minteer@asu.edu

\section{REFERENCES}

1. IUCN Red List of Threatened Species, Craugastor fleischmanni (www.iucnredlist.org/details/56603/0).

2. C. Moritz et al., Science 322, 261 (2008)

3. R. Puschendorf, F. Bolaños, G. Chaves, Biol. Conserv. 132, 136 (2006).

4. B. A. Minteer, J. P. Collins, Sci. Eng. Ethics 14, 483 (2008),

5. B. A. Minteer, J. P. Collins, ILAR J. 54,41(2013).

6. M. J. Ryan, F. Bolaños, G. Chaves, Science (2010); published online: www.sciencemag.org/content/329/ 5997/1272/reply.

7. J.P. Collins, M. Crump, Extinction in Our Times: Global Amphibian Decline (Oxford Univ. Press, Oxford, 2009)

8. E. Kolbert, The Sixth Extinction: An Unnatural History (Henry Holt, New York, 2014).

\section{ERRATA}

Editor's note: We are simplifying our procedure for making corrections to articles published in Science, while maintaining transparency for our readers. The full text and PDF files will be corrected online as soon as possible, with an explanation at the end of the full text and, for corrections involving data or metadata, in an accompanying online Erratum. A notification that an Erratum has been published online will appear in a subsequent print issue in this space.

Erratum for the Research Article: "Total Synthesis of a Functional Designer Eukaryotic Chromosome" by N. Annaluru et al., Science 344, 1254596 (2014). Published online 18 April; 10.1126/science. 1254596

Erratum for the Report: "Wild Pollinators Enhance Fruit Set of Crops Regardless of Honey Bee Abundance" by L. A. Garibaldi et al., Science 344, 1255213 (2014). Published online 2 May; $10.1126 /$ science.1255213

Erratum for the News \& Analysis: "Designer Microbes Expand Life's Genetic Alphabet" by R. F. Service, Science 344, 1255780 (2014). Published online 16 May; 10.1126/ science. 1255780

Erratum for the Report: “I-Love-Q: Unexpected Universal Relations for Neutron Stars and Quark Stars" by K. Yagi and N. Yunes, Science 344, 1250349 (2014). Published online 23 May; 10.1126/science. 1250349

Erratum for the Report: "Mapping the Cellular Response to Small Molecules Using Chemogenomic Fitness Signatures" by A. Y. Lee et al., Science 344, 1255771 (2014). Published online 23 May; 10.1126/science.1255771 


\section{Science}

\section{Specimen collection: An essential tool}

L. A. Rocha, A. Aleixo, G. Allen, F. Almeda, C. C. Baldwin, M. V. L. Barclay, J. M. Bates, A. M. Bauer, F. Benzoni, C. M. Berns, M. L. Berumen, D. C. Blackburn, S. Blum, F. Bolaños, R. C. K. Bowie, R. Britz, R. M. Brown, C. D. Cadena, K. Carpenter, L. M. Ceríaco, P. Chakrabarty, G. Chaves, J. H. Choat, K. D. Clements, B. B. Collette, A. Collins, J. Coyne, J. Cracraft, T. Daniel, M. R. de Carvalho, K. de Queiroz, F. Di Dario, R. Drewes, J. P. Dumbacher, A. Engilis Jr., M. V. Erdmann, W. Eschmeyer, C. R. Feldman, B. L. Fisher, J. Fjeldså, P. W. Fritsch, J. Fuchs, A. Getahun, A. Gill, M. Gomon, T. Gosliner, G. R. Graves, C. E. Griswold, R. Guralnick, K. Hartel, K. M. Helgen, H. Ho, D. T. Iskandar, T. Iwamoto, Z. Jaafar, H. F. James, D. Johnson, D. Kavanaugh, N. Knowlton, E. Lacey, H. K. Larson, P. Last, J. M. Leis, H. Lessios, J. Liebherr, M. Lowman, D. L. Mahler, V. Mamonekene, K. Matsuura, G. C. Mayer, H. Mays Jr., J. McCosker, R. W. McDiarmid, J. McGuire, M. J. Miller, R. Mooi, R. D. Mooi, C. Moritz, P. Myers, M. W. Nachman, R. A. Nussbaum, D. Ó Foighil, L. R. Parenti, J. F. Parham, E. Paul, G. Paulay, J. Pérez-Emán, A. Pérez-Matus, S. Poe, J. Pogonoski, D. L. Rabosky, J. E. Randall, J. D. Reimer, D. R. Robertson, M.-O. Rödel, M. T. Rodrigues, P. Roopnarine, L. Rüber, M. J. Ryan, F. Sheldon, G. Shinohara, A. Short, W. B. Simison, W. F. Smith-Vaniz, V. G. Springer, M. Stiassny, J. G. Tello, C. W. Thompson, T. Trnski, P. Tucker, T. Valqui, M. Vecchione, E. Verheyen, P. C. Wainwright, T. A. Wheeler, W. T. White, K. Will, J. T. Williams, G. Williams, E. O. Wilson, K. Winker, R. Winterbottom, and C. C. Witt

Science, 344 (6186), • DOI: 10.1126/science.344.6186.814

\section{View the article online}

https://www.science.org/doi/10.1126/science.344.6186.814

Permissions

https://www.science.org/help/reprints-and-permissions 